\title{
First report of 'Candidatus Phytoplasma trifolii' (16SrVI group) infecting cabbage (Brassica oleracea) in Turkey
}

\author{
Çiğdem Ulubaş Serçe ${ }^{1}$ (D) Salih Yılmaz ${ }^{1}$ \\ Received: 11 February 2019 / Accepted: 2 November 2019/Published online: 14 November 2019 \\ (C) Società Italiana di Patologia Vegetale (S.I.Pa.V.) 2019
}

Keywords Phytoplasma $\cdot$ Cabbage $\cdot$ ITS region $\cdot$ SecA gene $\cdot$ PCR

Brassica oleracea is an economically important vegetable species. It is a member of the Brassicaceae family and widely cultivated worldwide as well as in Turkey. During late summer and autumn seasons of 2014 and 2015, a total of 331 cabbage samples exhibiting phytoplasma-like symptoms, such as deformation of leaves, abnormal coloration, stunting and failure to head were collected from in Niğde province located in Central Anatolia Region of Turkey. Total nucleic acids were extracted from leaf midribs of plants using the total nucleic acid isolation protocol (Prince et al. 1993). For initial screening of the samples, double nested PCR method was applied. 16SrRNA gene of DNA samples was amplified by direct PCR using P1/P7, followed by two sequential nested PCRs using R16F1/B6 and M1/M2 primer pairs, respectively. Out of 331, 29 of the samples revealed the expected $\sim 500 \mathrm{bp}$ amplicons after the last nested PCR with M1/M2 primer pair. In order to sequence bigger portion of the genome, the P1/P7 products were amplified with R16F2n/R16R2 primer pair. The obtained $1132 \mathrm{bp}$ sequence belonged to TR-Lah19 isolate (GenBank accession No. MK392369) and had 99\% identity with 'Candidatus Phytoplasma trifolii' isolate from tomato plant (KY047614). Non ribosomal secA gene of the same isolate was amplified using SecAfor $1 / \operatorname{Sec} A r e v 3$ primers. Sequenced 772 bp nucleotides (MK392370) revealed 98\% identity with previously published $\sec A$ gene sequences of 'Ca. P. trifolii' (KX784498) species belonging to the clover proliferation (CP) group (16Sr-VI). The CP group of phytoplasma infections in cabbage was previously reported in Iran and India (Salehi et al. 2007; Khasa et al. 2018). To best our

Çiğdem Ulubaş Serçe

culubas@gmail.com; cigdemserce@nigde.edu.tr

1 Department of Plant Production and Technologies, Ayhan Şahenk Faculty of Agricultural Sciences and Technologies, Niğde Ömer Halisdemir University, 51240 Niğde, Turkey knowledge this is the first report of CP group phytoplasma infection of cabbage in Turkey.

Funding information This study was partially funded by Doğuş Tarımsal Projeler Ar-Ge Hizmetleri A.Ș.

\section{Compliance with ethical standards}

Conflict of interest The authors declare that they have no conflict of interest.

Ethical approval This article does not contain any studies with human participants or animals performed by any of the authors.

\section{References}

Khasa E, Rao A, Rao GP (2018) Molecular characterization of 'clover proliferation'phytoplasma subgroup-D (16SrVI-D) associated with vegetables crops in India. Physiol Mol Biol Plants 24(2):203-210

Prince JP, Davis RE, Wolf TK, Lee IM, Mogen BD, Dally EL, Bertaccini A, Credi R, Barba M (1993) Molecular detection of diverse mycoplasma like organisms (MLOs) associated with grapevine yellows and their classification with aster yellows, X-disease, and elm yellows MLOs. Phytopathology 83:1130-1137

Salehi M, Izadpanah K, Siampour M (2007) Characterization of a phytoplasma associated with cabbage yellows in Iran. Plant Dis 91:625630

Publisher's note Springer Nature remains neutral with regard to jurisdictional claims in published maps and institutional affiliations. 